\title{
DEFEASIBILITY OF MINERAL INTERESTS UNDER THE ALBERTA TORRENS SYSTEM
}

\author{
RONALD V. CLARKE* AND WILLIAM N. RICHARDS**
}

\begin{abstract}
When Sir Robert Torrens designed his system of land registration, one of his paramount objectives was the indefeasibility of the certificate of title, coupled with an assurance fund to compensate those persons who suffered loss through the misfeasance of the system or through a registrar's error. In the following article, the authors, by referring to statute and case law, critically analyze the system which, in relation to surface titles, is undeniably successful, yet in relation to mineral titles, is sadly deficient. The authors review the various exceptions to indefeasibility-fraud, prior certificate of title and misdescrip. tion, as well as the s. 64 implied exceptions. The rationale of the assurance fund, and the reason for the failure of the fund to serve as the compensatory feature envisaged by Torrens, is examined. The procedure involved in a complete historical search of the mineral title (both as to unpatented Crown lands and freehold lands) is described in detail, including specific problems such as "refills", tax forfeitures, and court orders; the value of a mineral certificate; and the various branches of the government which must be consulted. As well, the Land Titles Office practice of maintaining a "file" of confidential information (generally inaccessible to lawyers) is criticized. The authors then look at the question of determining ownership of mines and minerals under. lying bodies of water. Three aspects of the law of riparian rights are considered-the ad medium filum rule, accretion, and avulsion. The problem of determining mineral ownership under road allowances and the unique statutory provisions regarding railway lands and Soldier Settlement Lands are discussed, Finally, the authors evaluate the purpose, use, and effect of the registrar's caveat.
\end{abstract}

\section{INTRODUCTION}

The fundamental and overriding concept of all Torrens land system legislation is that the bona fide purchaser for value is entitled to rely upon the apparently correct and current state of the register and, upon acquiring a certificate of title based on that reliance, to look to the legislation to guarantee the indefeasibility of his title. (Theoretically at least, it follows that all bona fide purchasers and registered owners should enjoy the protection of this guarantee of indefeasibility, and not only the current bona fide purchaser.) If this concept had been translated into practical reality and if the system were free of error, the consideration of a majority of the problems raised in this paper would have little merit or purpose. But the unfortunate registered owner whose once inviolable title has been extinguished by the vagaries of the system or the bona fide purchaser for value caught by a statutory exception to indefeasibility does not worship at the Torrens altar and he finds small comfort in the idealism and platitudes of Sir Robert Torrens.

Insofar as it relates to minerals, the problems and difficulties inherent in the system are wide ranging enough for us to suggest that, at least in cases involving deprivation of mines and minerals interests held by early owners in the title chain, indefeasibility is the exception rather than the rule. While the Torrens system has operated very successfully as it relates to surface lands, its deficiencies where mineral

\footnotetext{
- Barrister and Solicitor, Burstall, Clarke, Jones and Coady, Calgary, Alberta.

** Barrister and Solicitor, Hurlburt, Reynolds, Stevenson and Agrios, Edmonton, Alberta.
} 
interests are concerned are legion. It is our main contention that statutory exceptions to the indefeasibility of registered mineral interests and other considerations outside the Torrens statute preclude a reliance on any certificate of title or duplicate and require those dealing with mineral interests to conduct historical title investigations. In their treatise, Canadian Oil and Gas, Lewis and Thompson have pointed out: 1

It is an inherent weakness of the Torrens system that a single exception from indefeasibility will necessitate historical search and deprive the system of much of its utility.

It is not only the Torrens statutes that create these problems and difficulties. As Messrs. Lewis and Thompson have stated: ${ }^{2}$

But while it is clear that the Torrens systems in Canada enable the bona fide purchaser for value to rely on the register (and without actually examining it) the extent to which 'the register is everything', or to the contrary, is to be subjected to defeasance by the operation of legal and equitable principles outside the statute, has been uncertain from the beginning. Recent cases have accentuated these uncertainties (emphasis added).

We would also suggest that if the assurance fund created under the

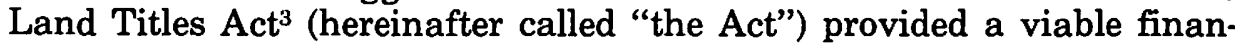
cial recourse to the holders of aborted mineral interests, the determination of ownership of those mineral interests would be a matter of more concern to the legal academic than to the oil operator.

It is our purpose in this paper to review the exceptions to indefeasibility and to highlight other problems affecting or bearing on title to mineral interests under the Torrens system. For the most part, references will be to Alberta legislation, but the majority of the difficulties are also inherent in the Saskatchewan legislation, as the Land Titles Acts of both Provinces have been modelled after the original Australian statute. After dealing with the broad spectrum, we will devote some time to certain specific areas of difficulty, namely, mineral rights to Soldier Settlement Lands and minerals under water, railways and highways. We will also have a few comments to make on the Registrar's caveat.

\section{EXCEPTIONS TO INDEFEASIBILITY}

The basic approach to indefeasibility of title and the exceptions to that indefeasibility are set forth in sections 63 and 65 of the Act: ${ }^{4}$

63. (1) The owner of land in whose name a certificate of title has been granted shall, except in case of fraud wherein he has participated or colluded, hold it, subject (in addition to the incidents implied by virtue of this Act) to such encumbrances, liens, estates or interests as are notified on the folio of the register that constitutes the certificate of title, absolutely free from all other encumbrances, liens, estates or interests whatsoever except the estate or interest of an owner claiming the same land under a prior certificate of title granted under the provisions of this Act or granted under any law heretofore in force and relating to title to real property.

(2) Such priority shall, in favour of any person in possession of land, be computed with reference to the grant or earliest certificate of title under which he or any person through whom he derives title has held possession.

65. (1) Every certificate of title granted under this Act (except in case of fraud wherein the owner has participated or colluded), so long as the same remains in

\footnotetext{
1 Vol. 1, para. 53.

2 Vol. 1, para. 52.

R.S.A. 1970, c. 198.

- Id.
} 
force and uncancelled under this Act, is conclusive evidence in all courts as against Her Majesty and all persons whomsoever that the person named therein is entitled to the land included in the same for the estate or interest therein specified, subject to the exceptions and reservations mentioned in section 64 , except so far as regards any portion of land by wrong description of boundaries or parcels included in the certificate of title and except as against any person claiming under a prior certificate of title granted under this Act or granted under any law heretofore in force relating to titles to real property in respect of the same land.

(2) For the purpose of this section that person shall be deemed to claim under a prior certificate of title who is holder of, or whose claim is derived directly or indirectly from the person who was the holder of, the earliest certificate of title granted, notwithstanding that the certificate of title has been surrendered and a new certificate of title has been granted upon any transfer or other instrument (emphasis added).

Additional implied exceptions to indefeasibility are described in section 64. (These provisions are set forth on the form of all Certificates of Title in the upper left hand portion thereof except on those certificates issued after April 1, 1973 in the South Alberta Land Registration District.): ${ }^{5}$

64. (1) The land mentioned in any certificate of title granted under this Act is, by implication and without any special mention therein, subject to

(a) any subsisting reservation or exceptions including royalties contained in the original grant of land from the Crown,

(b) all unpaid taxes, including irrigation and drainage district rates,

(c) any public highway or right of way or other public easement, howsoever created, upon, over or in respect of the land,

(d) any subsisting lease or agreement for a lease for a period not exceeding three years, where there is actual occupation of the land under the same,

(e) any decrees, orders or executions, against or affecting the interest of the owner of the land, that have been registered and maintained in force against the owner,

(f) any right of expropriation that may by statute be vested in any person, body corporate, or Her Majesty, and

(g) any right of way or other easement granted or acquired under the provisions of any Act or law in force in the Province (emphasis added).

While we do not intend to present an exhaustive analysis of these exceptions to indefeasibility, it should be useful to categorize the more important exceptions and to make some general comments on their application:

\section{Subsisting Reservations or Exceptions in the Original Grant of Land From the Crown}

It has long been the administrative and legislative policy of both the Federal Government (the owner of all mineral rights in Alberta prior to 1930) and the Provincial Government to except or reserve mineral rights in their grants. The Hudson's Bay Company, certain railway companies, The Saskatchewan Land and Homestead Company Limited, and a few individuals, received grants unrestricted as to mines and minerals, but approximately ninety percent of all mineral rights in $\mathrm{Al}$ berta are now held by the Crown in the right of the Province of Alberta pursuant to the legislative transfer of those rights to it in 1930. As a general rule, a complete reservation or exception of all mines and minerals is or was fully set forth in the initial grant or patent from the Crown but, even if this were not done, a subsisting statutory reservation might nevertheless be in effect. For example, The Public Lands Act ${ }^{6}$ and The Mines and Minerals Act ${ }^{7}$ contain severe overriding restrictions

\footnotetext{
s Id.

6 R.S.A. 1970, c. 217.

R.S.A. 1970, c. 238 .
} 
and limitations on the disposition or transfer of minerals by the Province and it appears that in the event of conflict between these Acts and the Act the former will prevail as they deal specifically with Crown lands and minerals whereas the Act deals with land generally.

The Courts have consistently held that the title of the Crown in the right of Canada cannot be defeated by the application of any provincial statute. Even if the Federal Crown has registered its title to the lands under the Act and thereby, by implication, submitted to its jurisdiction, it is highly unlikely that the validity of its ownership could be challenged under any provincial law. One could therefore be dealing with a registered owner whose title contained no apparent reservation of mines and minerals and be defeated by the application of the Federal statute.

Three specific examples of the paramountcy of Federal legislation in the area of implied or statutory mineral reservations should be noted. In disputes that have been tried concerning the ownership of minerals underlying lands administered by The Soldiers' Settlement Board of Canada, apparently indefeasible mineral titles created under the provincial statute have been defeated and recognition given to the ownership of the Federal Crown. Secondly, in dealing with railway minerals, bear in mind that section 136(2) of The Railway Act $^{8}$ will, in most instances, negate the railway's apparent mineral title unless the same have been expressly purchased by the railway. Thirdly, if your lands appear to be in or near an Indian Reserve, remember that these lands continue to be vested in the Federal Crown and did not pass to the Province of Alberta in 1930.

On the other hand, the reservation of mines and minerals to a volunteer or stranger (including the Crown) in a transfer is not effective and may be defeated. The Registrar's authority to correct such an error against the volunteer or stranger has been recognized by the Courts. ${ }^{9}$ Mines and minerals may not, in these cases, be acquired by the party named in the mineral reservation, the basic proposition being that you cannot transfer by way of reservation.

If the Crown does not apparently hold any registered mineral interest, be careful to ensure that ownership of mines and minerals is not vested in the Crown or one of its agencies under a Provincial or Federal statute.

\section{Fraud}

The cases have emphasized that the fraud required to defeat title must be dishonesty of some kind and not what we know of as constructive or equitable fraud. A bona fide purchaser is not bound to enquire into the circumstances under which the land was acquired by his transferor nor will knowledge of a prior unregistered interest or claim deprive the winner of the race to the Land Titles Office of his title, for such knowledge is not considered fraud under the Act. ${ }^{10}$ The Courts have not even looked disfavourably upon a registered owner who, having full knowledge of an interest properly caveated against his title, effected the lapse of that caveat and then asserted that he held free title. ${ }^{11}$

n.S.C. 1970, c. CR-2 (formerly s. 198 of The Railways Act, R.S.C. 1952, c. 234).

${ }^{9}$ Kaup v. Imperial Oil Ltd. (1962) 37 W.W.R. 193; Shorb v. Public Trustee (1954) 11 W.W.R. 132.

10 Supra, n. 3 at s. 203.

"Bensette and Campbell s. Reece (1969) 70 W.W.R. 705; Reversed [1973] 2 W.W.R. 497. See also Union Bank v. Boulter Waugh Ledd. (1919) 58 S.C.R. 385. 
The application of this exception to indefeasibility is not too important to the historical searcher until he reaches the current title, for once a bona fide purchaser for value appears on the scene, a fraudulently obtained title may be the root of a valid title in the new purchaser. Fraud appears to apply only as between the registered owner and his immediate predecessor in interest and, once rights for value have been conferred by the fraudulent party, the acquiring bona fide purchaser probably acquires an indefeasible interest, notwithstanding the infirmity of his grantor's title.

\section{Prior Certificate of Title}

If you are merely relying on the current certificate of title, you cannot be certain that there is not a prior existing certificate of title without conducting an historical search. First in time is first in right in this instance, unless the prior certificate of title is blemished. We have encountered cases where old titles containing many lands and interests were not fully conveyed or cancelled and, to the extent these titles were uncancelled, they would, in our opinion, be deemed to be prior existing certificates. It would appear that if the prior certificate of title on which a claim against the assurance fund is based has been cancelled, even though wrongfully or by error, the claim will not succeed. In the Turta case, ${ }^{12}$ petroleum had been reserved by the C.P.R. in its transfer to Podgorny and presumably remained in the C.P.R. title but since the clerk had, by error, cancelled the C.P.R.'s certificate, the Court held there was no prior certificate of title on which to base the claim. From an equitable point of view, one wonders why the wrongfully cancelled title should not prevail over the later title. True, each prospective dealer in the mineral interest would have to conduct an historical search to determine whether a preceding title had been improperly cancelled, but this casts no greater burden on such a person than the one which exists now where it is quite conceivable that a title may have issued to a mineral interest actually reserved to a former owner whose title has not been cancelled. Perhaps the onus should be on the person who could have, by historical search, avoided loss rather than on a person who may have had no opportunity to correct the error before its consequences became irreparable because he had no knowledge that it had occurred.

\section{Misdescription}

The important point to note here is that the omission from a certificate of title of a reservation and exception of mines and minerals does not constitute a "wrong description of boundaries or parcels included in the certificate of title". In addition, the Turta case is authority for the proposition that, since the Registrar's function is merely to transcribe what is set forth in the transfer submitted to him for registration and not to describe land, the Registrar cannot misdescribe land. Past judicial disputes have primarily involved surface rights, but even in this area the nature and extent of this exception to indefeasibility has not been fully defined. It is, however, clear that the Registrar may not correct misdescribed titles where rights for value may be prejudiced.

\section{Corrections}

While the foregoing exceptions to indefeasibility and the others mentioned in the Act may necessitate the conduct of an historical search, 
the frequency of problems encountered is small in comparison with the major difficulty of considering and interpreting both errors on the register and the attempts to correct or resolve those errors by Land Titles Office officials. Errors and corrections of errors are not uncommon in the chain of title to freehold mineral properties, and the difficulty one encounters is in assessing the meaning and validity of those corrections and their effect on the ownership of the minerals in question.

The Registrar's statutory powers of correction are set forth in section 185 of the Act but most of that section deals only with the power of the Registrar to obtain the duplicate certificate of title for the purpose of making a memorandum thereon or for wholly or partially cancelling it. Finally, the last subsection states: ${ }^{13}$

185. (4) In the case of any duplicate certificate or other instrument within the provisions of subsection (1) the Registrar, whether or not the duplicate certificate or other instrument is in his custody or has been produced to him in answer to his written demand, so far as practicable without prejudicing rights conferred for value, may cancel, correct or complete the register, and may wholly or partially cancel any duplicate certificate or other instrument and may correct any error or make any entry or addition in the duplicate certificate or other instrument or in any entry, memorandum or other endorsement thereon or in any memorial, duplicate certificate, exemplification or copy of any instrument made in or issued from the Land Titles Office and may supply entries omitted (emphasis added).

The Courts have narrowly confined the right of the Registrar to make corrections to the register with the result that the Registrar's power of correction is limited, for practical purposes, to the correction of clerical errors in cases where rights for value have not intervened. The Registrar should only correct as between the immediate parties to the transaction and once a bona fide third party for value has appeared on the register, he should be very hesitant in making any corrections whatsoever. These provisions in the Act were intended to strengthen the concept of indefeasibility for if the Registrar had unlimited power to correct, there would be little certainty in the register. ${ }^{14}$

It is evident that while the ambit of the registrar's statutory power of correction has been judicially and affirmatively declared to be limited to 'so-called clerical errors', negatively, it suffices to say that the power cannot be exercised where the result would be to trench upon the paramount provisions in the same statute ensuring the registered owner indefeasibility of title.

Unfortunately, Land Titles Office officials have, until recent years, ignored the limitations on their powers of correction imposed on them by the Act and by the Courts. Even after the Turta case, the officials have continued to make corrections to titles after rights for value had been conferred. The party that usually suffers as a result of these corrections is not the current bona fide purchaser for value examining his vendor's title, but the old certificate of title holder whose rights have disappeared from the register as a result of the correction.

Prior to the commercial discoveries of Leduc in 1947, ownership of petroleum was not a matter of great interest to landowners or the title clerk at the Land Titles Office. As a result, many titles were issued in which ownership of mines and minerals was either improperly included or omitted. It is not unusual to review early transfers that reserved mines and minerals and find that a titles clerk has deleted a mineral reservation or altered its wording with the result that the new

\footnotetext{
13 Supre, n. 3 at s. 185(4).

14 DiCastri, Thom's Canadian Torrens System 286 (2d ed. 1962).
} 
certificate of title either contains no reservation, or an improper reservation of the minerals in question. On occasion a mineral reservation has been added to the new title where none existed before. If the Land Titles Office subsequently discovered the error, corrections might be made not only to the current title but to all the intervening cancelled titles back to the point where the error took place. The fact that such corrections are ineffective has been confirmed by the Supreme Court of Canada in the Turta case.

In conducting a recent search we encountered the following wording in a transfer:

... do hereby transfer to [name of transferee] all our right title and interest in the said lands, reserving unto ourselves and our assigns the right of ingress, egress and regress and the right to use the land as may be reasonably necessary for the recovery and transportation of such minerals.

You will note that the first reference to minerals occurs at the end of the alleged reservation. The clerk obviously interpreted these words as effecting a full reservation of minerals for the title that issued contained the words "Reserving Thereout all mines and minerals". The Land Titles Office, having now discovered the error, refuses to issue a mineral certificate to either the preceding or the current title holder! The parties are virtually compelled to have a court reference to settle ownership.

The misspelling of a word or the shifting of position of words, the addition of new punctuation and, worst of all, an interpretation of words by an inexperienced and inadequately trained clerk can have a very real effect on the ownership of minerals. Once a new title has issued to a bona fide purchaser, that "correction" cannot be recorrected or revised and an indefeasible title has therefor been created by error. Small wonder that title insurance companies want no part of Torrens.

In these cases of error and correction, properly registered owners have been deprived of their indefeasible titles. From the deprived owner's point of view, we question whether the Act should not protect the properly registered owner of mineral interests from the loss of those interests by Land Titles Office errors and omissions. Why should the latest bona fide purchaser for value succeed over the early bona fide purchaser who has done nothing to contribute to his loss? The Torrens drafters, recognizing this deficiency (and others) in the system, created the assurance fund to provide compensation for those deprived of valid registered interests.

\section{Dower}

The provisions of the Dower Act, ${ }^{15}$ as it now exists, and the earlier legislation must be kept in mind to ensure that a transfer is not void or voidable due to failure to comply with this legislation. It should, of course, be pointed out that when dealing with a subsequent title holder who is a bona fide purchaser for value, Torrens principles overcome any concern one may have had with such a defect.

\section{THE ASSURANCE FUND}

Indefeasibility of title in favour of a bona fide purchaser for value is sometimes attained at the expense of a person who has been deprived of title as a result of error or fraud. Since the title of that bona fide 
purchaser is purportedly indefeasible, the deprived owner should have a remedy. Under the Act he is supposedly entitled to money compensation for his loss from the assurance fund.

If the basic cornerstone of the Torrens system, i.e., indefeasibility of title, is to remain intact, the deprived owner cannot get his land back so it seems to follow that he should be as fully compensated for his loss as is reasonably possible if access to the assurance fund is to be considered an adequate remedy. If this is not the case then why, from an equitable point of view, should the Torrens system protect the current bona fide purchaser at the expense of the prior owner whose title was also acquired in good faith and for value? Remember the assurance fund is supposed to protect those who have suffered loss or damages because their title is good, not because it is in any way deficient.

To make this protection effective, the deprived owner should have free and easy access to the fund but in mineral claims this is not the case. While claims arising out of the loss of surface rights are unlimited as to quantum and are not particularly difficult to pursue, the problems confronting the mineral claimant are virtually unsurmountable. Let us examine some of the conditions that must be met prior to concluding a successful action against the fund where minerals are concerned.

(1) The claimant must first be barred from bringing an action for the recovery of the land.

(2) If a question of dower is involved, the claimant is restricted to the remedies provided under the Dower Act. ${ }^{16}$

(3) If a third party is involved in the case of a claim arising from fraud or wrongful act, that person must be joined in the action. If the Court holds that the third party is liable, no judgment can be entered against the Registrar until the Court has made an order that the third party is judgment proof.

(4) Three months notice of the intended action must be served on both the Registrar and the Attorney General.

(5) The action must be brought within six years from the date the deprivation took place or in the case of error, omission or misdirection within six years of the time when the error, omission or misdirection was made. (Prior to 1949 the Act used the word "discovered" instead of "made".) So even though a deprived owner be diligent in prosecuting his claim from the date he becomes aware of the problem, he will no doubt be caught by the limitation period. The only way an owner can apparently protect himself against this time limitation is to methodically check and search all of his freehold mineral interests at the Land Titles Office every five years to ensure that he is not somehow been deprived of them. A mere reliance on the Duplicate Certificate of Title in his possession is not sufficient since the original Certificate could be amended or corrected without his knowledge.

(6) No action may be brought for damages arising out of a disposition of a mineral interest executed after March 29, 1949 unless the Registrar has issued a mineral certificate on that disposition. We advise all our clients to request mineral certificates when taking freehold mineral leases, but not solely to overcome one of the 
hurdles in the successful path to the fund. If nothing else, the client receives the benefit of a mineral historical search for five dollars, for the Land Titles Office in essence conducts a full mineral historical before issuing the certificate. However, if the slightest error or doubt is unearthed in that historical the Land Titles Office simply refuses to issue the certificate and the applicant is consequently denied access to the fund. The Registrar may alternatively file a Registrar's caveat setting forth the problem and then issue the mineral certificate subject to the caveat. In our experience we have noted that few oil companies even bother to request the certificate unless they are purchasing the mineral title (as opposed to leasing certain substances) for in that case the application is a prerequisite to effecting registration of the transfer. In view of the other restrictions mitigating against a successful application to the fund, many oil companies consider the application to be a waste of time and money.

Any protection afforded by the assurance fund is further weakened by section 178 of the Act which sets forth specific circumstances where the fund is not liable: ${ }^{17}$

178. The assurance fund is not under any circumstances liable for compensation for loss, damage or deprivation

(a) occasioned by the owner's breach of any trust whether express, implied or constructive, or

(b) in any case in which the same land has been included in two or more grants from the Crown, or

(c) in any case in which loss, damage or deprivation has been occasioned by land being included in the same certificate of title with other land through misdescription of the boundaries or parcels, unless it is proved that the person liable for compensation and damages is dead or has absconded from the Province or has been adjudged insolvent, or the sheriff has certified that he is not able to realize the full amount and costs awarded in an action for such compensation, or

(d) by reason of the improper use of the seal of a corporation or the want of a capacity in a corporation to deal with the estate or interest involved or to execute or take the benefit of the instrument registered, or

(e) by reason of the registration of an instrument executed by a person under legal disability, unless the fact of the disability was disclosed on the instrument.

Even if he is able to satisfy all these prerequisites and conditions the mineral claimant is, nevertheless, limited to total damages not exceeding one thousand dollars for each acre of mines and minerals lost.

In the Turta case, the C.P.R. claimed that its loss was $\$ 5,000,000$ and because the limitation period had run, the C.P.R. was ostensibly left without any recourse whatsoever. Subsequent to the final adjudication of the Turta case, and following a report by the Benchers' Special Committee on Titles to Minerals in Alberta in $1956,{ }^{18}$ the provincial legislature passed the Mineral Interests Compensation Act ${ }^{19}$ with a view to creating a three year quieting period for mineral claims against the fund. This Act, popularly referred to as an "Act to Benefit the Canadian Pacific Railway Company", granted owners deprived of minerals, as a result of Registrar's error, the right to commence an action against the Registrar for recovery of damages. Damages awarded could not exceed one thousand dollars per acre. While this Act circumvented the limitation periods, no actions could be brought thereunder after

1: Supra, n. 3.

in (1956) 1 Alu. L. Rev. 185.

19 S.A. 1958 , c. 43. 
March 31, 1961. We understand a number of actions were commenced under this Act and the C.P.R. finally received $\$ 160,000$ compensation for the loss of its petroleum interest to Turta under a consent judgment.

Amounts in the assurance fund in excess of $\$ 75,000$ are transferred to the general revenue of the Province. It is to be hoped that in the event a successful claim in excess of that amount were proved, that the government would similarly pay the excess out of general revenue notwithstanding the fact that the fund had been exhausted.

In considering the financial limitations on claims against the fund in mineral cases, the Report of the Benchers' Special Committee states: ${ }^{20}$

This Committee urges that in Alberta, where such tremendous amounts of money accrue yearly to the Government from dispositions of mineral rights and where, indeed, almost fifty percent of the annual revenue of the Province is derived from these sources, it is an anomaly to circumscribe the assurance fund with such severe restrictions, particularly as applicable to claims relating to mineral rights.

(In fairness it should be pointed out that prior to the statutory adoption of portions of the Benchers' Report, including the maximum of one thousand dollars per acre recovery provision, the limit on recovery was only the cost paid to acquire the minerals and damages of five thousand dollars.)

At the time of the Benchers' Report, it was estimated that $\$ 3,800,000$ had been paid into the assurance fund and less than $\$ 75,000$ paid out. While the figures are not readily available, it does not seem unreasonable to assume that, in view of the development of this Province in the last two decades, payments into the fund now exceed $\$ 25,000,000$. We are not aware of any substantial judgments against the fund. As indicated by the Benchers at that time, ". . . payments which have been made into the fund have represented little more than an additional tax on land transactions". If this was a correct view of the picture in 1955, the concept is certainly more relevant in 1973 .

Land Titles officials will argue that since the oil companies have contributed little to the fund (no fund fee is payable on the filing of a caveat) they should not be heard to complain about the deficiencies of the fund. While this may be true, since the oil companies rarely acquire a certificate of title and tend to protect their leasehold interests by way of filing a caveat, if we consider government revenues as a whole and the monies paid into government coffers by the industry in the form of bonuses, rentals, royalties and various taxes, it seems to us that the oil industry is certainly paying its way in this Province.

In conclusion, we would suggest that you continue your practice of (1) conducting historicals on mineral interests, (2) recommending the acquisition of mineral certificates, and (3) advising your clients to recheck their mineral interests periodically at the Land Titles Office, for the assurance fund is not going to be of much help to anyone suffering mineral title losses.

\section{THE HISTORICAL SEARCH}

As we have seen, the exceptions to indefeasibility, the problems created by Registrar's errors and corrections, and the inadequacy of assurance fund compensation make the conduct of an historical search a virtual necessity. The solicitor who, in rendering opinions on mineral interests, fails to conduct an historical title investigation (particularly on freehold) would at least be derelict in his duty to his client and

20 Supra, n. 18 at 207. 
might be subject to a claim for negligence should his opinion be relied upon and damages flow therefrom.

Let us assume that your client has advised you that he is going to drill on a given parcel of land or that he is going to purchase that parcel. In either case he will want to be as certain as possible that his working interest has been obtained from the correct owner of the minerals and that the title of that owner is valid and indefeasible. We make it a practice to advise our client, in advance, of the various types of searches we intend to conduct and point out that our opinion will be based on those searches. If our client does not wish a particular search to be carried out which we feel is necessary or advisable, we inform him that our opinion will be limited accordingly.

As a first step, we write a letter to the Land Titles Office requesting information as to whether the lands are patented or unpatented both as to surface and mines and minerals. If the Land Titles Office advises us that their records indicate that there is no patent registered for the lands as to surface and mines and minerals, we will, subject to any other applicable statutory restrictions, and after checking with the Department of Lands and Forests to ensure that no patent has been issued or is pending, advise our client that the lands are not subject to the Act and are held by Her Majesty the Queen in the right of the Province of Alberta.

The Land Titles Office has discontinued its practice of providing a letter representing that lands and/or the minerals thereunder are unpatented and consequently not subject to the Land Titles Act. Apparently fearing that some patent might be in existence which is not recorded on their index cards or has not been presented to the Land Titles Office, the officials now simply provide you with an abstract from the index. In that form of "abstract" it is expressly stated that there is no guarantee, representation or warranty that the information contained therein is correct or may be relied upon. It is not an abstract as we know it for patented land. Since the information provided affords us no protection as to its accuracy, we make a practice of checking the card index ourselves after we have received the initial report. While the Land Titles officials do not normally care to see anyone behind the counter, they will usually allow a solicitor access to the cards.

In our initial letter to the Land Titles Office, we will request current surface and mines and minerals abstracts on any freehold lands and, depending on the client, a surface abstract on unpatented Crown mineral lands. We also request a general registration certificate on any registered owner or registered interest claimant to ensure there are no "decrees, orders or executions, against or affecting the interest of the owner of the land, that have been registered and maintained in force against the owner. . .."21 If we are working on proposed unit lands we will submit a list of all royalty and working interest owners and request a single general registration certificate on one owner with all the remaining interest holders added as "extra references", mainly because this procedure is cheaper.

While awaiting the Land Titles Office report, we forward letters to (1) the Department of Mines and Minerals, (2) the Taxation Division of the Department of Mines and Minerals and (3) the Energy Resources Conservation Board. In the first case, we request a search letter covering any petroleum and/or natural gas grant made by the Crown covering

21 Supra, n. 3 at 8. 64(e). 
the lands in question. While the purpose of this search letter is to ensure that the working interest in the grant is as you expected it to be, and that the grant is valid, subsisting and in good standing, there is some comfort in the fact that the Crown impliedly claims title to the lands. The Taxation Division and the Conservation Board will give you the status of applicable area taxes, producing taxes and Board taxes. ${ }^{22}$ Since the municipalities do not have the power to tax mineral rights, tax inquiries are not usually made to the municipalities where the lands are situated unless you are interested in taxes that might be outstanding on wellsite materials.

When we receive notification from the Land Titles Office that our requested materials are ready, we personally attend at the Land Titles Office to conduct the necessary searches. If you encounter freehold minerals in the Calgary Land Titles Office, the clerk will provide you with a sketch or title tree of the historical chain of title, including the transfer or other instrument creating each certificate of title, and, while it may not always be completely accurate, a great deal of time can be saved by this procedure. You will see at a glance the degree of complexity of your historical chain of title and be able to ascertain the title development from the initial grant to the current title. If you do not receive this graphic title chain sketch, be sure to prepare one yourself as you conduct the historical for it will save you a great deal of confusion particularly if the chain becomes segmented and divided with partial interests and small lots being transferred out of the main title. If you attempt to construct a correct chain of title from a great number of written searches where you have numerous fractional parcels of less than one acre split off and five or ten consolidations of various interests you will find it very easy to make a mistake. The sketched chain of title will help you keep the development of the various surface and mineral interests and road and railway interests under control.

You have now checked the card index system and find that a portion of the lands are patented as to surface only (the minerals being unpatented Crown) and a portion are freehold. In the event your parcel contains acreage other than the usual surveyed amount you should attend at the Surveys Department and review the township plans. If you discover a river or a lake you should sketch it out for further reference. The township plans will give you full details about the amount of acreage in the section or quarter on any side of the lake or river. By the way, the Land Titles Office will not give you a "no patent" abstract or letter or any other type of information on this water acreage. You will have to make up your own mind as to ownership. The lake, river, or other acreage is likely to be excepted from the initial grant from the Crown.

Having decided that you want to do the easy work first, you commence your searches on the unpatented Crown mineral acreage. We normally check the patent, patent title and current title for any patented surface. If the original Crown grant or patent contains an adequate mineral reservation we are virtually assured that the Crown owns the minerals in question since each following title will be subject to that reservation whether or not it is expressly set forth in that title (subject to the Humboldt case ${ }^{23}$ in Saskatchewan). As a precaution and in an effort to discover any possibility of the lands having been

$\because$ See supra, n. 3 at s. $6.4(\mathrm{~b})$.

2.t Prudential Trust Co. Ltd. v. Humboldt Registrur|1957]S.C.R. 658. 
by error or otherwise dealt with as to mines and minerals on a certificate of title, we check the first title and the current title to ensure that they contain the same mineral reservation. You should also watch for misdescription between the initial grant and the first title issued by the Land Titles Office. We recommend this limited surface search procedure to our clients since a search of all surface titles becomes time consuming and expensive and the risk of minerals having somehow become involved in the surface chain of title is minimal. If the first title and the last title contain identical mineral reservations (and the cards indicate no confusion), the minerals would have had to appear on the register and to disappear between the first and the current title. In practice, our clients are prepared to take this risk on Alberta lands knowing that the Crown's title is virtually indefeasible. In Saskatchewan, we advise our agents to conduct complete historicals of the surface title as the Crown's title may be defeated by the inclusion of minerals in a surface title.

If the reservation in the grant or notification is not of all mines and minerals or if there is no reservation, be careful to ensure that a statutory reservation outside the Act does not effect a complete reservation. If the interest of the Crown is derived otherwise than from the original grant or pursuant to such a statutory reservation, then the considerations governing the search are the same as those governing the case of acquisition of oil and gas rights from a freehold owner.

If the amount of acreage described in the patent and patent title is not the same as in the current surface title or if this amount of acreage does not correspond with the acreage in your Crown lease or permit, you should conduct a full surface historical in an attempt to discover where and how the discrepancy arose.

As a further precaution ensure that none of the lands in question fall within the definition of Indian Reserves under section 10 of the Alberta Natural Resources Agreement for these lands continue to be vested in the Federal Crown and minerals underlying them did not pass to the Alberta Government in 1930. The further problem of Soldier Settlement lands is dealt with in another portion of this paper and suffice it to say that certain Federal Crown mineral rights underlying these Soldier Settlement lands may not have been conveyed to the Provincial Government.

\section{FREEHOLD}

Where the Crown has not made reservations of mines and minerals in its grant, we normally refer to these lands as "freehold". Every degree of care must be exercised in tracing the ownership of these interests. We check each title and each transfer or other document effecting a change in title or ownership in an attempt to develop an unbroken chain of title from the first grant to the current title. We also check each encumbrance or charge registered against the land by listing it on a sheet of paper and then checking it off as it is discharged in the chain of title. If you have any doubt as to whether a given charge or encumbrance affects mines and minerals, call up the instrument and review it. Hopefully your current title will list all past encumbrances in the proper order for, if it does not, problems can arise. For example, a caveator whose caveat was not properly brought forward in the chain of title and who consequently lost his interest to a 
bona fide third party for value without notice of his interest would be in the same position as a registered owner deprived of his title due to a Land Titles Office error. The result could be disastrous if you were relying on the priority of that disappearing caveat to sustain your interest.

You must ensure that each title is fully cancelled at least insofar as it concerns the lands you are searching or the spectre of a prior certificate of title may arise. It appears to make no difference whether that title was cancelled wrongfully. When each title is cancelled, reference will be made to the instrument effecting the cancellation. Care should be taken to ensure that the succeeding title is compatible and in accordance with the terms of the transfer instrument. If the preceding title is not cancelled and the transfer purports to reserve interests which are not described as being reserved on the new certificate of title, that preceding title could qualify as a prior certificate.

On the way through your historical search you may encounter every conceivable instrument contemplated by the Act and some instruments never anticipated by the draftsmen of the legislation. It might be useful at this stage to consider a few of these:

\section{The Refill}

When a title is endorsed with many encumbrances and charges and there is no space left on the certificate to add any further notarials, it is the practice of the Land Titles Office to "refill" the certificate to one or more succeeding certificates. Unfortunately errors can arise when the new certificate or certificates are created if the transcription is not carefully completed. We have seen instances of caveats not brought forward or recorded in the new titles in the improper order and have seen mineral substances disappear from the register altogether.

In conducting a recent search of certain C.P.R. lands, we noted that the patent title had been refilled to several new titles and the patent title subsequently cancelled in full. The problem was that the C.P.R. had reserved coal and petroleum in portions of the lands previously cancelled out of the patent title, but when the refill titles were issued, there was no reference to those coal and petroleum rights. The Land Titles Office now "revived" the patent title for the said rights and when the C.P.R. requested separate mineral titles for the rights, they were issued and the patent title was cancelled in full again. Not being aware of the Registrar's authority to "revive" cancelled titles, we had the temerity to question the procedure and were simply advised that it was a matter of policy to "revive" in these circumstances. We .concluded that, since no intervening rights for value appeared to have arisen between the date of the refill and the revival and no other titles had been created for the minerals, the C.P.R. was still the correct registered owner of the substances, the correction or revival being within the power of the Registrar. We wonder what the effect would have been if the petroleum had somehow been included in the main title to the lands held by a third party before the "revival" or contemporaneously with it. It appears the C.P.R. would have lost again since the patent title was cancelled in full and could not be construed as a prior certificate of title. 


\section{The Transmission}

Familiarize yourself with the provisions of the Act governing dispositions by executors, administrators and trustees, namely sections 123 to 127 inclusive.

\section{Tax Forfeiture}

If a certificate of title, including mines and minerals, has been cancelled for tax arrears, you should check the tax legislation to ensure that the taxing authority had the power to take the minerals. For example, by section 4 of the Minerals Titles Clarification Act ${ }^{24}$ the Registrar is given the authority to reinstate title to mines and minerals in cases where the taxing authority has acquired title to mines and minerals when pursuant to the applicable legislation it was only entitled to acquire surface rights. Section 4 of this Act states: ${ }^{25}$

4. Where under any tax recovery proceedings a title to land including any mines and minerals has been cancelled in full and the surface only of such land has been vested in the name of the taxing authority or in a bona fide purchaser for value from the taxing authority, the Registrar of Titles under The Land Titles Act is hereby authorized to reinstate the title as to the mines and minerals in the name of the owner at the time the title was cancelled in full.

You should also check the Mineral Titles Redemption Act ${ }^{26}$ to determine whether the owner may have held a right to recover title to forfeited minerals. In tax proceedings, the Department of Mines and Minerals will start by registering a claim for tax arrears. If the arrears were not paid a further charge would be registered directing the Registrar to cancel the certificate as to mines and minerals and stating that such mines and minerals were vested in Her Majesty in the right of the Province of Alberta. Certificates of title were not issued. After the passing of the Mineral Titles Redemption Act, many mineral titles were reinstated upon application pursuant to the Act but if the interests had been leased by the Department of Mines and Minerals, the previous owner could not redeem his interest until the lease or other grant expired although he received portions of the monies paid to the government under the terms of the lease or grant.

\section{Court Orders}

We have seen that the power of the Registrar to correct the register is severly limited both by the Act and by judicial pronouncements ${ }^{27}$ confirming and expanding upon those limitations. The power of the Court to correct the register is far wider ranging and, in fact, contains no apparent limitations. The scope of the Court's authority to correct is set forth in section 188 of the Act: ${ }^{28}$

188. (1) In any proceeding respecting land or in respect of any transaction or contract relating thereto, or in respect of any instrument, caveat, memorandum or entry affecting land, the judge by decree or order may direct the Registrar to cancel, correct, substitute, or issue any duplicate certificate, or make any memorandum or entry thereon or on the certificate of title and otherwise to do every act necessary to give effect to the decree or order.

\footnotetext{
2 R.S.A. 1970, c. 237.

${ }^{25}$ Id.

$=6$ S.A. 1958, c. 44

27 C.P.R. and Imperial Oil Limited v. Turta et al., supra, n. 12; In Re The Land Titles Act (1952) 7 W.W.R. (N.S.) 21; Re Heller (1960) 33 W.W.R. 385.

2* Supra, n. 3.
} 
The Courts have not been reluctant to rectify the register, particularly as between the parties to the disputed transaction. While hesitant to intervene when rights for value have arisen, the Courts will correct Registrar's mistakes and errors and will employ legal and equitable principals in resolving disputes between competing parties.

A recent decision of the Alberta Supreme Court, Public Trustee for Alberta v. Pylypow ${ }^{29}$ evidences the wide area of discretion claimed by the Courts in balancing equities between claiming parties. The case is particularly useful since the Court was compelled to consider a series of problems involving reservations and corrections made to those reservations by Land Titles Office officials.

In 1907, Mouncey and Cross each owned an undivided one-half interest in the lands in question, reserving unto the Canadian Pacific Railway all coal. In 1915, Mouncey and Cross conveyed their interests to Melnyk inserting a reservation of all mines and minerals to His Majesty in the transfer instrument. When Melnyk's title was issued it contained the following reservation: "Excepting thereout all coal, mines and minerals". In 1932 the reservation was crossed out by an official in the Land Titles Office and the words "Reserving unto the Canadian Pacific Railway Company all coal" were inserted. In 1923 Melnyk transferred to Pylypow, inserting a reservation of all mines and minerals. Pylypow's title originally contained the following reservation "reserving thereout all mines and minerals". In 1932 the reservation was crossed out by an official in the Land Titles Office and the words "Reserving unto the Canadian Pacific Railway Company all coal" were inserted.

The two corrections in 1932 were both made on the same date and in the first case the correction was made to a title which at the time was fully cancelled. In 1958 Pylypow transferred to Lopetinsky reserving coal to the C.P.R. (remember that his title had been corrected to show a reservation of coal only in 1932) and adding the following reservation as well: "Also reserving unto the said Transferor all Other Mines and Minerals". Lopetinsky's title correctly reflected the reservations made in the transfer to him. The Registrar filed a Registrar's caveat in 1971 giving notice that errors may have been made in the chain of title.

In considering whether the mines and minerals other than coal were held by (1) Mouncey and Cross interests, (2) Melnyk interests, or (3) Pylypow interests, the Court held:

(1) That the erroneous reservation of mines and minerals to the Crown in 1915 did not vest any mineral title in the Crown, the Crown being a volunteer or stranger (Shorb v. Public Trustee ${ }^{30}$ ).

(2) That the "reservation" to the Crown was not effectual to prevent the passing of the minerals to Melnyk. Since the reservation to the Crown was pure surplusage, the Court held that the transfer to Melnyk must be read as if it contained no reservation of mines and minerals at all.

(3) That all the alterations to the reservations were ". . . made without authority and thus without effect".

(4) That the Pylypow interests were entitled to a declaration that they owned the mines and minerals in dispute.

The Court was of the view that mutual mistake had occurred since

$2 y[1973]$ I W.W.R. 471.

: Supra. n. 9. 
Melnyk and Pylypow had laboured under the false premise that Melnyk did not know that he owned the mines and minerals when he transferred to Pylypow. The Court held that it could supply the intention of the parties and the agreement they would have made had they been aware of the correct mineral ownership position.

Sinclair J. stated:31

First of all I share the following view of Egbert J. at 688 of Shorb, supra:

'Apart from the evidence, I think I can take judicial notice of the notorious fact that in 1935 mines and minerals were, except in a very small area of the province, worthless, and that their presence or absence was not a material fact in negotiations over what was then regarded as purely agricultural land'.

Both parties were described as farmers in the transfer. It is apparent from Melnyk's affidavit forming part of the transfer that the land was used for farming.

After considering the principles relating to rectification of written instruments and the concepts of mutual mistake, Sinclair J. went on to say: ${ }^{32}$

The parties to the transaction are dead. As has been mentioned, the evidence before the Court is that contained in the documents themselves. Yet that evidence, coupled with the fact of which I have taken judicial notice, leads me irresistibly and overwhelmingly to the conclusion that Melnyk and Pylypow mistakenly believed that Melnyk was not entitled to the minerals, and that had such a mistake not occurred, Pylypow would have obtained, as a matter of course, whatever interest Melnyk had in the minerals.

We prefer this rational approach to the resolution of the ownership problem rather than the strictly legal and form, not substance, approach taken by the Manitoba Court in Re Moir's Estate and Will. ${ }^{33}$ In that case it was held that a devise of land excepting portions transferred to a railway company did not include the mines and minerals in the railway portions notwithstanding that the mines and minerals under the railway lands had not, by virtue of section 198 of The Railway Act, passed to the railway. The Court found that certain executors' transfers could not have conveyed the said minerals because since the railway lands were excepted that exception included above and below surface rights.

While the case is not on all fours with the Pylypow case, it seems to us that Sinclair J. would have reached a different decision than the Manitoba Court. Surely the executors in the Moir case had no intention of reserving the mines and minerals under the railway lands and laboured under the mistake that they held no interest in those minerals.

Unless the reasoning of the Court in the Pylypow case is adopted in the future, complex problems involving the determination of mineral ownership are bound to arise. There are a great number of situations involving roadway, railway and other fractional interests in mines and minerals where Land Titles Office officials have purportedly brought minerals forward in the main chain of title to the current certificate of title.

In the 1950's, many corrections were made to current certificates by adding the words "as to surface only" to the exception of a fractional parcel of land in the main title. Concurrently with that correction the Land Titles Office official would add a mineral reservation to the title for the fractional interest. The authority to make that latter correction

\footnotetext{
3 Public Trustee for Alberta v. Pylypow, supra, n. 29 at 473.

12 Id. at 474.

33 (1961) 36 W.W.R. 83.
} 
was sometimes non-existent and issues have been tried on the validity of those corrections, but for the most part the correcting authority was confirmed by legislation, i.e., The Mineral Titles Clarification Act. ${ }^{34}$ The major problem is to determine who should be vested with ownership to the mines and minerals. Should they go to the heirs and successors of the owner from whom the fractional interest was taken along the lines of the Moir decision or should they come forward in the chain of title in accordance with the reasoning of Sinclair $\mathrm{J}$. and the reasoning of the Land Titles Office officials (which long preceded the Sinclair judgment). As indicated, we feel the latter approach has more merit from a practical and logical point of view, for if the former view is adopted, the minerals may be truly lost from the register since it may be impossible or at least financially prohibitive to ascertain the identity of the persons entitled to the minerals. In addition, if the original title is cancelled and the minerals are held not to be included in the current certificate, there is no title whatever for the minerals in question.

[Editor's note: Since this paper was written, Mr. Justice Sinclair's decision in the Pylypow case was reserved by the Court of Appeal of Alberta, see [1973] 6 W.W.R. 673.]

\section{THE LAND TITLES OFFICE "FILE"}

Every now and then when you are searching titles historically you will, after reviewing many corrections and alterations to the titles, discover a notation on the title- "See File". The trouble is you will not, in most instances, be permitted access to that file. The Land Titles Office takes the position that the file contains confidential information which might be damaging to it in litigation. The files usually contain legal and other opinions and correspondence between the Land Titles Office and purported owners of mineral interests and the Attorney General's department. The purpose of all this correspondence and these opinions is to establish ownership of a given interest when a dispute has arisen without submitting the matter to the Courts. For example, if $\mathrm{A}$ and $\mathrm{B}$ will quit claim or acknowledge to $\mathrm{C}$ and the Land Titles Office that they have no interest in the disputed lands, the Registrar will then attempt to effect vesting of the interest in $C$. The file may also contain all the materials and reviews preparatory to a court reference. If you are able to gain access to the file in some manner, you can save a great deal of time you might normally spend to determine just what happened in the chain of title. It seems to us that any solicitor on any reasonable grounds should be permitted to review the file and it is to be hoped that the Registrars will relax their procedures in this regara in the future. We do not feel that the Land Titles Office should attempt to conceal errors or mistakes it has made with a view to protecting the assurance fund from claims, but to co-operate fully in the rectification of those errors and mistakes. One sometimes gets the impression that the Land Titles Office personnel are more interested in presenting an "error proof" image to the public than assisting in the resolution of title problems.

So now you have checked every title and transfer and any other applicable instrument in the chain. Naturally you should watch for possible misdescription problems by ensuring that the land description in

s4 Supra, n. 24. 
each title is identical to the one preceding it. The inconclusiveness of the definition of misdescription and of its effect make this check advisable. If you are dealing with a limited mineral reservation, ensure that the wording of the reservation is the same on every title. We came across a situation recently where an initial reservation of "all mines and mineral oils of every type and description" was ultimately changed to "reserving thereout all mines and minerals". The changes took place almost imperceptibly with a comma or word added or deleted in various transfers and certificates in the chain of title. We still have not been able to determine which title comprises certain of the minerals, let alone resolve the problem of whether the initial reservation could be interpreted to include natural gas.

If, in the course of checking the freehold chain of title, you find there has been a disposition to the Federal Crown, the Provincial Crown or one of its agencies, start checking the applicable law before you render an opinion as to the ownership of the mineral interest.

Ensure that the interest your client purports to claim is properly caveated or registered.

After you have completed your examination of the chain of title, review all your searches, numbering them in order of priority, complete your chain sketch of title and prepare your opinion there and then. Do not take your notes back to the office, and file them, and then attempt to complete your opinion a week or two later for you may easily overlook or forget a problem which you noticed when you were searching the titles.

One final word-do not use an inexperienced or improperly trained secretary or agent to conduct historicals on freehold minerals. Their lack of legal training may cause them to treat what appear to them as minor errors or omissions in a cavalier fashion and you may never become aware of the existence of a correction that may be crucial to your opinion. In addition, if you are conducting independent searches of the working interest and someone else is doing the Land Titles Office work, you may not be able to dovetail the lessor and lessee's interests properly.

To this point we have attempted to point out the general deficiencies of the Torrens system as it relates to minerals and to suggest methods of discovering and perhaps avoiding the problems created by those deficiencies. A few specific problem areas are worthy of further comment.

\section{WATER AND WATERCOURSES}

Probably the single most difficult question to answer when dealing with historical searches in Alberta relates to ownership of mines and minerals underlying water bodies, be they streams or still water. Fortunately, questions relating to ownership of mines and minerals due to the disappearance or change in location of a body of water appear to be relatively rare.

The whole topic may be generally discussed under the heading of riparian rights and from the point of view of the historical search, there are really three areas of concern:

(1) The ad medium filum rule;

(2) The law giving rise to accretion, or the converse situation where an increase in the level of a body of water takes place, or similarly where a bank of a river or stream changes position so that the bed 
of the stream encroaches upon land owned by someone other than the Crown; and

(3) The significance of avulsion, i.e., the relatively rapid change in the location of a body of moving water.

In Alberta and Saskatchewan, it seems fairly clear that as a general rule, the Crown is the owner of all mines and minerals lying beneath a body of water, whether the same is a lake, or slough, or river, or creek. ${ }^{35}$ It is possible that this rule may not be applicable prior to 1894 and it could be that a person other than the Crown could have acquired ownership to mines and minerals under a body of water if he had done so prior to 1894, even though he had not received a specific grant of the same. ${ }^{36}$

Riparian rights are generally any rights which a land owner enjoys by reason of the fact that he has adjoining his land, or crossing through it, a body of water or stream. These rights vary from jurisdiction to jurisdiction and include such things as permitting the land owner to take water for his own use, construct wharves or piers, navigate the waters, fish, take gravel or sand from the lake or stream bed, float timber in the water body, in some cases divert the course of the stream and perhaps remove mines and minerals lying beneath the body of water. ${ }^{27}$ An important riparian right is the right to the continuance of the flow of the water crossing the owner's land. In spite of some strong suggestions that there are no riparian rights in Alberta, it does appear that vestiges of these rights do continue. ${ }^{38}$

\title{
1. The Usque Ad Medium Filum Aquae Rule
}

This rule provides that the owner adjacent to a body of water (whether it be moving or still) owns the bed lying beneath the water body to the centre of the water body where his property will meet that of the land owner on the other side of the body of water. It appears that in Alberta and Saskatchewan at least, this rule does not apply. The position was considered by the Supreme Court of Canada in The King v. Fares et $a .^{39}$ and it was decided that while the Province of Saskatchewan accepted the laws of England which were in force on the 15th of July, 1870, and while the laws of England included the ad medium filum rule, such a rule did not apply in the Province of Saskatchewan by reason of the existence of the Dominion Lands Act and the Territories Real Property Act. What the court was considering there, was the ownership of the bed of Rush Lake, which had been drained to a fairly great extent by the C.P.R. The grant of land which was the subject of the dispute said simply:

\begin{abstract}
... all that parcel or tract of land situate ... in the 17th Township ... and being composed of the whole (fractional) of Section 12 of the said Township, containing by admeasurement 127 acres (more or less).
\end{abstract}

No reference was made in the legal description to "Rush Lake" or to a plan of survey showing the same. In short, it appeared that the legal description was in language most favourable to the reception of the pre-

\footnotetext{
:North-West Irrigation Act, S.C. L898, c. 35, s. 5; Public Lands Act, R.S.A. 1970, c. 297, s. 4; Land Titles Act, supra, n. 3 at 8. 64(1).

"t Irrigation Act, R.S.C. 1927, c. 104, ss. 6. 7 (Repealed by The Territorial Lands Act. S.C. 1950, c. 255, s. 26, but see s. 9 of that Act).

.17 39 Halsbury's Laws $510-348$ (3d ed. Simonds 1955); 67 Corpus Juris 682 et seq.

in Clarke v. The C'ity of Edmonton [1930]S.C.R. 1:37.

19 [1932] S.C.K. 78.
} 
sumption which is the usque medium filum aquae rule. However, the Court held that the land which had been covered by the lake remained the property of the Crown. Consequently, it appears clear that the Crown remains the owner of a stream or lake bed in circumstances where there is no specific reservation of the same from a grant of land even after the stream or lake ceases to exist. The Crown, therefore, can be taken to own the mines and minerals found within, upon or under the bed of such a body of water. ${ }^{40}$

\section{The Rule of Accretion}

The foregoing general rule enunciated in The King v. Fares ${ }^{41}$ must be limited somewhat in circumstances where the water body changes its extent or location in a slow and imperceptible manner. "Accretion" is the process of gradual, imperceptible addition to riparian lands caused by the action of water in washing up sand, earth, gravel or other materials. In determining whether an addition to land constitutes accretion, the length of time during which it is in the course of formation is of importance. If it is formed by a gradual, imperceptible deposit of alluvion, it is accretion, but, if the stream changes its course suddenly and in such manner as to destroy the integrity of the land in controversy and so that the land can be identified, it is not accretion. ${ }^{42}$ That the law of accretion is part of the law of Alberta today appears to be made clear in Clarke v. The City of Edmonton. ${ }^{43}$ In fact, the only way this case can be distinguished from the Fares case, which was decided by the Supreme Court of Canada two years later and which made no reference to the Clarke case, is that in Clarke the change was gradual or imperceptible while in the Fares case, Rush Lake was lowered quickly as a result of the drainage ditch constructed by the C.P.R. Clarke sued the City of Edmonton for trespass, alleging that the City dumped refuse on a bench located near the North Saskatchewan River and it was common ground that the bench had been built up over the years by the river depositing silt and other materials and that when the original patent was granted to Clarke, the bench in question was not in existence. Clarke's title simply provided that he was the owner of "all that portion of River Lot 21, lying to the north of a certain roadway" and that prima facie, it would appear that Clarke owned the land to the river's edge. The Supreme Court of Canada found this to be the case. It would follow of course, that Clarke would, in the absence of an express reservation, own the mines and minerals under the bench which was created by the river deposit. The rule of accretion and the ad medium filum rule appear to be little more than presumptions and thus if the patent or subsequent certificate of title are expressed in terms which define the boundary of the land in question in such manner that it clearly rules out the possibility of ownership to the water's edge, then it appears the rules cannot be relied upon. This appears to be true for the ad medium rule, ${ }^{44}$ and presumably it would be the same in connection with the law relating to accretion.

It may be useful to consider some examples of language used in patents and titles in an attempt to determine whether or not the rule

\footnotetext{
"Flewelling v. Johnson (1921) 59 D.I..R. 419 at 429 (Alta. A.D.); Public Lands Act, supra, n. 6 at ss. 4(1), 34(1).

4 Supra, n. 39.

12 39 Halsbury's Laws, supra, n. 37 at 511; 67 Corpus Juris, supra, n. 37 at 825.

4: Supra, n. 38 .

44 The King v. Fares, supra, n. 39 per Anglin J. at 8 ) and per Duff J. at 83.
} 
of accretion would apply in order that the owner could gain the benefit of the rule and be considered the owner of the mines and minerals lying beneath the derelict land, or, conversely, suffer the loss of the mines and minerals in the event that the water level rose and permanently flooded the land which was originally within his grant but not covered by water:

(a) Where the original grant or patent to land contains a description such as the following:

All of the North West Quarter of Section 21-46-13-W4M excepting

thereout those portions covered by the waters of X Lake,

then the grantee or patentee receives the right to accretion along with his title. In other words, as long as the grantee or patentee owns the land in the quarter, he is entitled to claim as being his, all land, both surface and minerals, which were at the time of the grant covered by water but which are no longer covered by water. The water must, however, have disappeared in a slow and imperceptible manner. ${ }^{45}$ That is, he would be the owner of such land to the extent of the boundary of the quarter section he was originally granted.

(b) Where the original grant or patent contains a description of land such as the following:

That portion of the North West Quarter of Section 16-24-13-W4M

bounded as follows: On the North East and South by the boundaries of the said quarter section and on the West by that line shown as the shoreline of the lake shown on plan of survey of the said township of record, etc., on the 4th day of July, 1892, etc.,

then the grantee or patentee probably does not receive the right to the derelict land along with his title. Should the body of water in such case recede, then the land lying between the boundary as shown on the plan above described and the new shoreline of the lake would remain the property of the Crown both as to surface and to minerals. This would, it is submitted, be due to the express words of the patent, the lands granted could with certainty be identified by reference to the survey plan. ${ }^{44}$

(c) Where the grant or patent from the Crown contains a description such as the following:

All those portions of the East Half and the North West Quarter of Section 35-46-23-W4M which are not covered by any of the waters of certain surveyed marshy lakes as shown upon a map or plan of survey of the said township approved and confirmed at Ottawa on the 1st day of August, A.D. 1892, etc., containing by admeasurement together 594 acres more or less,

then the grant would probably include the right of accretion. That is to say, such a grant would be similar to that in proposition (a) above and would produce the same results. There is some doubt about this proposition. The argument would have to be that the language in the patent referring to "the lands covered by the marshy lake" are dominant and take precedence over the reference to the survey plan, the reference to the plan simply being descriptive of the lake, rather than setting the boundaries of the grant of land. ${ }^{47}$

(d) A variation of paragraph (c) above would be where the sketch

\footnotetext{
15 Clarke v. The City of Edmonton, supra, n. 38.

th The King v. Fares, supra, n. 39 at 80, 83.

1: Foster v. Wright (1878) 4 C.P.D. 438.
} 
plan of August 1, 1892, shows the lake in a different location from subsequent plans of the same quarter section. This would likely strengthen the original grantee or patentee and all of the lands in the quarter section not covered by the water would likely become his.

(e) If the title is of the same language as paragraph (c) above, but the plan of August 1,1892, showed no reference to a stream which was subsequently shown to appear on subsequent surveys of the same quarter section, if the stream existed on August 1, 1892, and was a stream coming within section 4(1) of the Public Lands Act, ${ }^{48}$ then the mines and minerals within, upon or under such stream bed would be excepted from the original grant or patent and would at all times be owned by the Crown. This would be true apparently, regardless of whether or not there is an exception stated in the original grant or patent with respect to the stream bed. Were the stream to appear after the date of the plan of August 1, A.D. 1892, then it would still be possible for the mines and minerals within, upon or under the stream bed to be Crown mines and minerals. This rule does not appear to apply in the event that the stream had come suddenly upon the quarter section in question. The matter could presumably be treated in the same manner as would a rise in water level of the lake to cover an area that was not covered by water in $1892 .{ }^{49}$

(f) A recent Privy Council decision ${ }^{50}$ contains an interesting discussion of the application of the rule of accretion. The case considered a Crown grant where the land grant was described by metes and bounds and one of the boundaries was the "sea beach". The sea beach was, however, described as running in a straight line for a certain number of feet from a certain point. Notwithstanding this fact, the court held that the rule of accretion applied to the grant and the size of the grant would increase or decrease as the line of medium high tide changed in a gradual and imperceptible fashion.

Perhaps it should be noted that it does not matter whether the build-up of materials and land (with a corresponding reduction in water level) is done by natural or artificial means so long as it is gradual and imperceptible. ${ }^{51}$ Perhaps it should also be noted that when speaking of water bodies generally, it is the high water mark which is to be taken as the edge of an owner's property. The land between the high water and low water marks was at common law, the property of the Crown. ${ }^{52}$ This appears to be the case in the west today as well.

\section{Avulsion}

A further case might be mentioned as well, that is the case where a water body suddenly changes course. The easiest example would be where a river or stream broke out of its original banks and began to travel over a new area and create a valley for itself. In such a situation, the mines and minerals under the new bed would likely be retained by the original owner. Similarly, the Crown would likely retain the mines and minerals under the original bed of the river. ${ }^{53}$

\footnotetext{
is Supra, n. 6.

49 Yukon Gold Co. v. Boyle Concession (1916) 10 W.W.R. 585 at 595 (B.C.C.A.), aff'd (1920) 50 D.L.R. 742 at 744.

${ }^{30}$ State of Penang v. Beng Hong Oon [1972] 2 W.L.R. 1.

is Standly v. Perry (1880) 3 S.C.R. 356.

s2 39 Halsbury's Laws, supra, n. 37 at $5 \mathbf{5} 77.5559$.

s3 67 Corpus Juris, supra, n. 37 at 828.
} 


\section{REGISTRAR'S CAVEAT}

Since February 2, 1971, the Registrar of the Land Titles Office for the North Alberta Land Registration District has filed approximately 150 caveats under the power granted to him under section 155 of the Land Titles Act. ${ }^{54}$ In all but the last 12 of the caveats, the Registrar claimed an interest by reason of the caveats on behalf of Her Majesty the Queen. In the latest caveats, no reference is made to a claim on behalf of Her Majesty as the Registrar now appears to be of the view that the Crown likely has no interest in the circumstances under which the Registrar's caveats are filed. To date, it has not been the practice of the Registrar of the Land Titles Office for the District of South Alberta to make the same extensive use of section 155.

Section 155 of the Land Titles Act reads: $: 55$

155. The Registrar may file a caveat on behalf of Her Majesty, or on behalf of any person who may be under any disability, to prohibit the transfer or dealing with any land belonging or supposed to belong to the Crown or to any such person, and also to prohibit the dealing with any land in any case in which it appears to the Registrar that an error has been made in any certificate of title or other instrument, or for the prevention of any fraud or improper dealing (emphasis added).

While the section may be capable of more than one meaning, ${ }^{56}$ it appears that the Registrar should only invoke the section when either Her Majesty or a person under disability needs protecting. ${ }^{57}$ If the caveats were only filed in such circumstances, the section would conform to the other provisions in the Land Titles Act relating to the registration of caveats as presumably any other person who had an interest in a parcel of land would be free to file a caveat. However, it is apparently the practice of the Registrar to file a caveat in any situation which might involve a problem in a mineral title chain without regard to the fact that apparently no person suffering a disability or the Crown requires protecting. Presumably the Registrar takes the position that where there is a possible title problem, there is a potential claim against the assurance fund and it is that interest of Her Majesty which he is attempting to protect. Such a use of the section, however, appears to be contrary to the spirit of the Land Titles Act. 58

The effect of registering such a caveat appears to be far reaching. By registering his caveat, the Registrar can prohibit the dealing with any land in which there appears to be an error in a chain of title. The existence of such a caveat then, could prevent the development of a mineral property.

The Registrar of the North Alberta Land Registration District is of the opinion that the mineral interest may still be dealt with after the registration of the Registrar's caveat but it should be noted that the section appears "to prohibit the dealing" with the land after the caveat has been registered. Again, from a practical point of view the Registrar's position seems justified. In the past the Registrar, on discovery of the existence of an error, refused to accept any instruments affecting the problem interest with the result that many executors

\footnotetext{
$\therefore$ Supra, n. 3.

s. Id.

it I.e., "and" in the section may create two separate situations where Registrar's caveats may be filed.

$\therefore$ DiCastri, supra, n. 14 at $605-607$

sn Id. at 606-607. For what is submitted to be the correct use of the Registrar's cavent, sec Re Prudential Trust Co., supra, n. 23. C'. In Re Section 70 Land Titles Act (1953) 10 W.W.R. 68 at 76.
} 
could not even transmit title to minerals where an error became apparent in the chain of title. Everything stopped and the minerals remained in limbo, hardly a desirable state of affairs and inconsistent with the Torrens concept of certainty of the register. Nevertheless, if dealings after the registration of the Registrar's caveat (and always subject to it) are permitted, the difficulties in ascertaining correct ownership may increase as time passes. It cannot be expected that each case will be litigated and resolved due to financial considerations and so there will always be a substantial number of lands passing from owner to owner with the title cloud.

Without providing an exhaustive list, the following are some of the factual circumstances in which the Registrar has seen fit to file a caveat pursuant to section 155:

(1) Where there were unauthorized corrections in a chain of title, i.e., roadway, railway, tax forfeitures;

(2) Where there was no consent of spouse annexed to a mineral disposition on a title early on in a mineral chain (where the property could have been a homestead) although it appeared that the current registered owner was a bona fide purchaser for value who could presumably rely upon the indefeasibility sections of the Land Titles Act;

(3) Where there was an uncertainty as to the ownership of the mines and minerals under a C.P.R. railway right of way in circumstances where the caveat would presumably protect the interest of the C.P.R.;

(4) Where there was a reservation to a stranger (the reservation having been later corrected by an Assistant Deputy Registrar) and where there was a subsequent bona fide purchaser for value;

(5) Where the current registered title holder to the mines and minerals, although a bona fide purchaser for value, was at the end of a chain of title which commenced from a transfer which purported to transfer the mines and minerals although the transferor, in fact, only had title to the surface of the land in question.

The question which must be answered by a person requested to give a title opinion is what should be done in cases where the Registrar has filed a caveat. It is submitted that even if the person rendering the opinion is satisfied that he can warrant ownership of the mines and minerals in a particular title, in spite of the existence of the Registrar's caveat, he should exercise discretion and advise that no expense should be incurred to prove the mineral claim until the Registrar's caveat has been removed from the current title. The Land Titles Act provides a procedure whereby an aggrieved person may make an application by way of originating notice to the Supreme Court of Alberta for a declaration that the Registrar has no interest in the subject land and for an order that the Registrar remove his caveat. ${ }^{59}$ In addition, the applicant could ask the court for a declaration that he has a good, valid and subsisting certificate of title to the mines and minerals in question and that any lease has been granted is a proper and valid one.

\section{SOLDIER SETTLEMENT LANDS}

The fact that the Soldier Settlement Board or the Director of Soldier Settlement has from time to time held certificates of title evidencing

\footnotetext{
s9 Supra. n. 3 at 8. 151.
} 
ownership to land in the western Provinces demonstrates vividly the need for the historical search. It appears clear that there is little doubt about the proposition that the Federal Government or one of its agen cies can avail itself of the Provincial Land Titles procedures and hold title to the land and at the same time not be bound by the usual provisions of the Land Titles Act.60 The Soldier Settlement Board or the Director of Soldier Settlement can assert its title to the mines and minerals lying within, upon or under the land in spite of the fact that the soldier settler or a bona fide purchaser for value purchasing through him has received title to the mines and minerals where the same have been transferred to the settler in the face of a legislative prohibition, as the cases have held that the provisions for indefeasibility found in the Land Titles Act do not affect the titles of the Crown in the right of Canada. Consequently, the historical searcher must be ever mindful of this particular hazard and must check carefully all situations in which a chain of title shows that the Crown in the Right of Canada, or one of its agencies, is or was the holder of lands. Besides the Soldier Settlement Board or the Director of Soldier Settlement, Indian lands, lands within National Parks or lands held by the Director, the Veterans Land Act $^{61}$ must be examined with care.

The Soldier Settlement Board case involves circumstances in which the Board or the Director acquired a parcel of land from a freehold owner, Her Majesty in Right of Canada, or some federal agency such as the Department of Indian Affairs. Title to the parcel was then created by the local Land Titles Office when the Board or the Director registered its transfer, as apparently the transfer served as the patent or similar grant from the Crown. ${ }^{62} \mathrm{~A}$ title then was created standing in the name of the Board or the Director which did not contain a reservation of mines and minerals.

Section 57 of the Soldier Settlement Act provides: ${ }^{63}$

57. From all sales and grants of land made by the Board, all mines and minerals shall be and shall be deemed to have been reserved, whether or not the instrument of sale or grant so specifies, and as respects any contract or agreement made by it with respect to land it shall not be deemed to have thereby impliedly covenanted or agreed to grant, sell or convey any mines or minerals whatever.

A variation on the above factual situation would be a case in which the Soldier Settlement Board advanced funds or made a loan to a settler who had acquired land, including mines and minerals, independently of the Board. The Board would secure its loan by taking a mortgage on the land of the settler which mortgage would be in the Land Titles form and duly registered in the local Land Titles Office. The settler would then go in default under the mortgage and the Soldier Settlement Board would foreclose the land in question and obtain title to the land without any reservation of the mines and minerals. The Board then, typically, would later sell the land which it had foreclosed without reservation of the mines and minerals to a bona fide purchaser for value. This case would differ from the preceding one in that the mines and

so Attorney.General of Canada v. Toth (1956-59) 27 W.W.R. (N.S.) 230 (Sask. Q.B.); Re Land Titles Act Re Director of Soldier Settlement (1960) 31 W.W.R. (N.S.) 647 (Alta. S.C.); Re Director of Soldier Settlement of Canada (1971) 18 D.L.R. (3d) 94 (Sask. Q.B.).

61 It appears, however, that the Veterans Affairs legislation does not contain a restriction similar to 8 . 57 of the Soldier Settlement Act.

6. The Soldier Settlement Act, R.S.C. 1927, c. 188, s. 51; Attorney.General of Canada v. Toth, supra, n. 60 at 236.

63 S.C. 1919 (later R.S.C. 1927, c. 188). 
minerals in question would clearly have come within the Land Titles system in a regular fashion and the Soldier Settlement Board could not rely upon the exception to indefeasibility contained in section 64(1)(a) of the Land Titles Act. ${ }^{64}$ It is submitted that the validly enacted Federal legislation would, however, be paramount and the Soldier Settlement Board would remain the owner of the mines and minerals in question in spite of any such a transfer. ${ }^{65}$ The bona fide purchaser for value would be left to his remedies against the assurance fund, although in these circumstances there may not be a remedy as it is difficult to say that the loss or damage sustained was by reason of an error, omission or misdescription. ${ }^{66}$ However, it is our understanding that, on application, the Crown may validate the current title by way of a grant under The Public Lands Grants Act.

Another variation might be where the Soldier Settlement Board acquired its title by relying upon the indefeasibility provisions of the Land Titles Act which altered the common law rule of nemo dat qui non habet. For example, suppose the Registrar failed to give effect to a reservation of mines and minerals in a transfer and wrongfully cancelled in full the certificate of title out of which the interest created by the transfer was to have been derived. The new title created would then include the mines and minerals and if that title was subsequently passed on to bona fide purchasers for value, they would be able to rely upon the Land Titles Act as giving them ownership to the mines and minerals. Suppose one of these bona fide purchasers for value was the Soldier Settlement Board who then passed on the property to a further similar purchaser. In these circumstances, it may be that the Soldier Settlement Board could obtain the benefit of the Land Titles Act but not be bound by it to its detriment, ${ }^{67}$ with the result that section 57 of the Soldier Settlement Act would keep the mines and minerals in the Soldier Settlement Board and deprive the subsequent purchaser.

A further complication surrounds the 1930 agreement whereby the Province acquired the natural resources which had up to this point been retained by the Federal Government. ${ }^{68}$ Clause 13 of that agreement provides: ${ }^{69}$

13. All interests in Crown lands in the Province upon the security of which any advance has been made under the provisions of The Soldier Settlement Act, being Chapter 188 of the Revised Statutes of Canada, 1927, and amending Acts, shall continue to be vested in and administered by the Government of Canada for the purposes of Canada.

The effect of this provision may be that in some cases, mines and minerals are reserved to the Federal Government. It might become important to examine the surface chain of title (particularly the title which was current on May 29, 1930), to see whether or not the registered owner is shown to be the Soldier Settlement Board and, if so, to check into the matter more closely to see whether or not the Federal Govern-

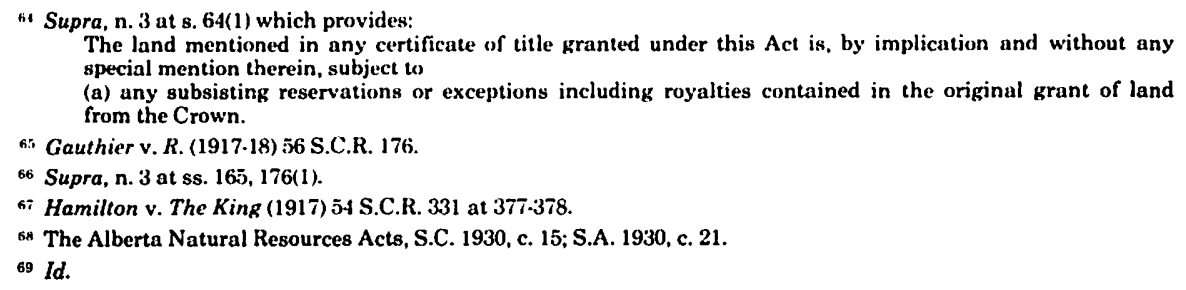


ment claims an interest in the mines and minerals in opposition to a similar claim of the Province of Alberta.

\section{HIGHWAYS}

The government of the Province of Alberta claims ownership of all mines and minerals lying beneath all road allowances laid out by the grid survey system as distinguished from roads taken by surveyed plan. It appears the Province acquired any interest the Federal Government had in roadways in $1905 .^{70}$

Since the Statute Law Amendment Act ${ }^{71}$ it has been fairly clear that unless the same were expressly purchased or otherwise acquired by the Crown, the Province did not obtain an interest in any mines or minerals found to exist within, upon or under the highway right of way acquired pursuant to the provisions of the Land Titles Act. ${ }^{72}$ The Mineral Titles Clarification Act ${ }^{73}$ makes this situation clear for the period prior to the commencement of the Statute Law Amendment Act of 1911-12.

The Mineral Titles Clarification Act also appears to give Legislative sanction to any corrections made by a Registrar of Land Titles giving effect to the fact that the Crown does not acquire any rights in the mines and minerals in these cases. ${ }^{74}$ Apparently any mines and minerals expressly acquired by the Crown for roadways or similar uses may be returned on application to the Minister of Mines and Minerals. ${ }^{75}$

In spite of the foregoing legislation, this area is not completely free from problems. It is fairly common that when a registered owner of a parcel of land which includes mines and minerals and which has had a roadway or highway right of way carved out of it transfers the same, he reserves from the transfer "all that portion shown on filed plan containing acres more or less". The subsequent title that is created and each successive title thereafter then contains a reservation in the above terms and the question becomes whether the current title holder acquires the mines and minerals under the area referred to in the reservation. It appears that if the reservation does not expressly exclude mines and minerals, then the same are taken to be reserved. Invariably, however, the Land Titles Office has cancelled the title from which the roadway or highway right of way was originally carved, and no one then apparently has title to the mines and minerals under the road in question. Just who is the owner of the mines and minerals in such a case remains in doubt. If the general rule that the words of the reservation govern (and as no exception is

\footnotetext{
is The Saskatchewan and Alberta Roads Act, S.C. :905, c. 38. (This Act was repealed by the Saskatchewan and Alberta Roads Act, 1906, R.S.C. 1906, c. 100, which while similar in terms, contained the following clause:

8. Nothing herein contuined shall be construed to vest in the Crown in the right of the Province any mines or minerals under any part of any road or trail upon or through Dominion lands.

Presumably, however, s. 8 was not an attempt to reserve any such mines and minerals to the Federal Government, but simply declaratory of the fact that no such interest existed as it appears the Federal Government divested itself of its whole interest in the roadways located within the jurisdictions which are the subject of this Act); K.S.C. 1927, c. 180.

"S.A. 1911-12, c. 4, s. 15(26). (Carried forward in successive Land Titles Acts and now found at R.S.A. 1970, c. 198, s. 93(2). The situation has continued since 1930. The Mines and Minerals Acts, supra, n. 7 .

12 See the Land Titles Act, supra, n. 3 at s. 93(1). One problem is that the document creating the title as referred to by its day book number is often not capable of production at the Land Titles Office when roadways are created and thus the searcher has no way of being certain that the mines and minerals are not expressly acquired by the Crown.

:. Supra, n. 24 at s. 2(1)

"Id. s. 2(2).

:- The Mines and Minerals Act, supra, n. 7 at s. 24.
} 
expressed for the mines and minerals, title to the same does not pass), the result would be cumbersome and not in line with common sense.

As the terms of the reservation vary from case to case, each case must be examined individually. However, two arguments may be raised in favour of the current certificate of title holder of the balance of the lands receiving the mines and minerals under a roadway which has been taken from the parcel. One is that any such exception is only intended to cover that portion of the land granted to or taken by the Crown. ${ }^{76}$ The other is that there is a rebuttable common law presumption that the abutting owner owns the soil (and hence the mines and minerals) under a roadway ad medium filum. ${ }^{77}$

\section{RAILWAYS}

Another area of concern when doing historical searches involves railway rights of way where the same have been carved out of existing certificates of title which included ownership of the mines and minerals.

The key to the consideration of this question is what is now section 136(2) of the Railway Act ${ }^{78}$ and the fact that this section was held to be within the legislative competence of the Federal Government by the Supreme Court of Canada in the Reference brought by the AttorneyGeneral of Canada and opposed by the Canadian Pacific Railway Company and the Canadian National Railway Company. ${ }^{79}$ The relevant portion of that section is: ${ }^{80}$

All such mines and minerals . . . shall be deemed to be excepted from the conveyance of such lands [railway rights of way], unless they have been expressly named therein and conveyed thereby.

The effect of the section is that, since February 1, 1904, the general position found in Alberta is reversed for those companies acquiring railway rights of way which are governed by the Railway Act. Presumably, any railway rights of way acquired prior to 1904 which did not specifically reserve the mines and minerals to the person from whom the rights of way were acquired, would include the mines and minerals within, upon, or under the right of way as would be expected in the usual course of such a transfer.

The question, then, is what rights of way are covered by section 136(2). The Supreme Court of Canada left little doubt about one proposition: that is that all of the rights of way acquired by the Canadian Pacific Railway Company after February 1, 1904, are governed by section 136 of the Railway Act and thus that company did not acquire any right to the petroleum, natural gas or other mines and minerals lying beneath such of its rights of way. This appears to be the case whether the same were acquired by expropriation or by purchase so long as the company would have the right to acquire the right of way by expropriation in the absence of reaching an agreement with the owner of the lands in question to purchase the right of way. ${ }^{81}$

\footnotetext{
is Siple v. Blow (1903) 8 O.L.R. 5.17 (Ont. C.A.); Wright v. Jackson (1886) 10 O.L.R. 470.

: O'Connor v. Nova Scotia Telephones (1893) 22 S.C.R. 276; In Re The Land Titles Act, Ex Parte Jackson [1928] 1 W.W.R. 337 at 344 (Alta. A.D.). Cf. Camrose (Town) v. Thom and Thompson (1956) 18 W.W.R. (N.S.) 139.

is Supra, n. 8.

ig [1958] S.C.R. 285.

so Supra, n. 8 at $8.136(2)$.

"I Supra, n. 79 at 296 per Rand J., and at 313 per 1 ocke J.
} 
The same can be said for the Canadian National Railway, at least for the period between February 1, 1904, to June 6, 1919.82 For the period between June 6,1919, and June 14, 1929, however, the Supreme Court of Canada expressly refused to decide whether or not the provisions of section 136 of the Railway Act applied to the rights of way acquired by the Canadian National Railway as it did not wish to interfere with rights of persons not given an opportunity to be represented before it. ${ }^{83}$ In making the statement, it would appear that $\mathbf{M r}$. Justice Locke was satisfied, on the material before him, in any event, that the exclusionary provision of the Railway Act did not apply to the C.N.R. during the years in question. It is to be noted that the Supreme Court of Canada did not have any hesitation in interfering with the rights of the C.P.R. in an adverse fashion as it was before the Board, and thus presumably it can be concluded that the Supreme Court was in agreement with the submissions of the C.N.R. It is to be noted also that counsel for the Attorney-General of Canada was prepared to concede that the restrictive sections of the Railway Act did not apply to the C.N.R. for the years in question. In addition, two other cases lend support to the view expressed above. ${ }^{84}$ C.N.R.'s position is different from the C.P.R.'s because, under the provisions of the Canadian National Railway Act, the C.N.R. acquired its right to obtain railway rights of way pursuant to the Federal Expropriation Act, which act did not contain a restriction similar to section 136 of the Railway Act, and accordingly, in the absence of a reservation made by the transferee when the land was purchased or otherwise acquired, the C.N.R. acquired the mines and minerals under the right of way as well, as would be expected in the normal case of such an acquisition.

Over the years, there have been a great number of railway companies, most of which have ended up becoming part of either the C.N.R. or the C.P.R., but it does appear important to examine the legislation relating to each such company when a title chain indicates it has acquired a railway right of way..$^{85}$ Another class of railways may be those with wholly provincial undertakings. It could be that such systems

"2 Id. at 313 per Locke J. (applies to the Canadian Northern Railway and the Grand Trunk Pacific, as they then were).

8 Id.

"t C.N.R. v. Harricana Goldmine Inc. (1943) 3 D.L.R. 529 at 535 (S.C.C.); Reference Re Jurisdiction of the Exchequer Court, Canadian National Railway Company v. Boland [1926] S.C.R. 239 at 240 . Cf. Boland v. C.N.R. [1926] 4 D.L.R. 193 (P.C.).

*s An act respecting Canadian Pacific Railway Company and Certain Subsidiary Companies, S.A. 1957, c. 106, purports to turn over four compunies to the Canadiun Pacific Railway Company. They are: The Alberta Railway and Irrigation Company, Lacombe and Northwestern Railway Company, Manitoba Southwestern Colonization Railway Company, and The Alberta Central Railway Company. The Alberta Central Railway Company was incorporated by a Federal act, S.C. 1901 , c. 47. and thus the Company was subject to the Federal Railway Act. Section 2 of the Act incorporating the Alberta Central Railway Company declared it to be a work for the general advantage of Canada.

The 1957 Alberta act also dissolved the Lacombe and Northwestern Railway Company. This company was apparently incorporated pursuant to S.A. 1909 , c. 48. (The name was changed under S.A. 1919, c. 29, s. 1(6)). This company appeared to be subject to the Provincial Railway Act in a manner similar to the Canadian Northwestern Railway Company.

An act respecting Canadian Pacific Railway Company and certain wholly-owned subsidiaries, S.C. 1957, c. 40, appears to vest in the Canadian Pacific Railway Company the following companies: British Columbia Southern Railway Company. The Columbia and Western Railway Company. The Kaslo and Slocan Railway Company. The Kootenay and Arrowhead Railway Company, Nakusp and Slocan Railway Company, The Nicola, Kamloops and Similkameen Coal and Railway Company, The Shuswap and Okanagan Railway Company. The Alberta Central Railway Company, The Alberta Railway and Irrigation Company, Lacombe and Northwestern Railway Company. The Great Northwest Central Railway Company, and Manitoba SouthWestern Colonization Railway Company.

The Federal Statute also purports to dissolve the following companies: The Kootenay and Arrowhead Railway Company, Nakusp and Slocan Railway Company. The Shuswap and Okanagan Railway Company, The Alberta Central Railway Company. The Alberta Railway and Irrigation Company. The Great Northwest Central Railway Company, and Manitoba Southwestern Colonization Railway Company. 
are not subject to the Federal Railway Act. Such a company may be the Canadian Northern Western Railway Company, which came into existence by reason of an act to incorporate a company of that name. ${ }^{86}$ The Company was empowered to construct and operate two railway lines (by later amendment similarly empowered to construct several other lines) wholly within the Province of Alberta. The Company clearly appears to have been subject to the provisions of the Railway Act, ${ }^{87}$ but the Railway Act referred to appears to be the provincial one. ${ }^{88}$ As originally enacted, the Provincial Railway Act did not make any provision with regard to the acquisition of mines and minerals by railway companies within, upon or under lands acquired by them for rights of way (although some provincial incorporating acts did ${ }^{89}$ ). However, the Provincial Railway Act was amended by adding the following section: ${ }^{90}$

80(c) The Company shall not, unless the same have expressly purchased, be entitled
to any mines, ores, metals, coal, slate, mineral oils, or other minerals in or under
any lands purchased by it or taken by it under compulsory powers given it by this
Act, except only such parts thereof as are necessary to be dug, carried away or
used in the construction of the works, and all such mines and minerals except as
aforesaid shall be deemed to be excepted from the conveyance of such lands unless
they are expressly named therein and conveyed thereby.

That amendment was not assented to until February 16, 1912, so that if the Canadian Northern Western Railway Company is intra vires the Province of Alberta, and not subject to the Federal Railway Act, there would be a two-year period in which that Company could have acquired the mines and minerals under its rights of way.

Even if it can be taken that the foregoing accurately sets out the law relating to the mines and minerals underlying railway rights of way, it is immediately obvious that the reversal of the usual situation caused by section 136 of the Railway Act will leave, in most cases, an uncertain position in a chain of title. The reason is that the title from which the right of way has been carved will, in all likelihood, be shown to be "cancelled in full" as to the railway right of way. Should the property later be transferred to a bona fide purchaser for value, in all likelihood the exception for the railway right of way as shown on the transfer will not have expressly excluded from it the mines and minerals. Thus the subsequent purchaser will acquire his title in the land, excepting the railway right of way, and likely not acquire the mines and minerals under the railway right of way. ${ }^{91}$ In the meantime, in the usual situation the Registrar will have cancelled the title of the transferee and thus the mines and minerals under the railway right of way will be in limbo; they will not be in the title of the railway company by reason of section 136 of the Railway Act; they will not be in the title of the subsequent purchaser by reason of the exception of the railway right of way; and while the original transferee may be entitled to become the registered owner of the mines and minerals under the railway right of way in question, his title will have been "cancelled in full". In such circum-

\footnotetext{
s6 S.A. 1910 (Second Session), c. 48 (Assented to December 5, 1910).

s? Id. s. 5 .

ss S.A. 1907 , c. 8.

89 An Act to Incorporate The Alberta North-Western Railway Company, S.A. 1906, c. 53 .

90 S.A. $1911-12$, c. 15.

9t Re Moir Estate, supra, n. 33.
} 
stances, it is submitted that it is impossible to warrant the ownership of the mines and minerals under the right of way in question. The Registrar's practice seems to be to bring the railway minerals forward to the main current title by correction. 